\title{
Farklı Sulama Düzeylerinin Serada Yetiștirilen Domatesin Verim ve Kalitesine Etkisi
}

\author{
Ali Fuat TARI*
}

Mesut SAPMAZ

Harran Üniversitesi Ziraat Fakültesi Tarımsal Yapılar ve Sulama Bölümü, Șanlıurfa

\begin{abstract}
*Sorumlu yazar e-mail (Corresponding author e-mail): aftari@harran.edu.tr
Geliș tarihi (Received) : 13.02.2017

Kabul tarihi (Accepted): 13.02.2017

DOI : $10.21657 /$ topraksu.339821
\end{abstract}

\section{Öz}

Bu çalıșma, serada yetiștirilen domates (Lycopersicon esculentum Mill cv. Astona) için en uygun sulama programının olușturulması amacıyla, 2012-2013 yetiștirme sezonunda Akdeniz iklimi koșullarında yürütülmüștür. Araștırma tesadüf blokları deneme deseninde üç tekerrürlü olarak yürütülmüș ve dört ayrı sulama konusu ele alınmıștır. Sulama konularının olușturulmasında açık su yüzeyinden meydana gelen buharlașma miktarlarının farklı oranları (\%60, \%80, \%100 ve \%120) esas alınmıștır. Araștırma sonucunda, sulama düzeylerinin, domates verimi ve bazı kalite kriterleri üzerine önemli etkilerinin olduğu belirlenmiștir. En uygun sulama programı olarak açık su yüzeyi buharlașmasının \%100'ünün verildiği uygulama bulunmuștur. Bu konunun sulama suyu gereksinimi, su tüketimi, verimi ve sulama suyu kullanım randımanı sırasıyla 350 mm, $361 \mathrm{~mm}, 128.7 \mathrm{t} \mathrm{ha}^{-1}, 36.8 \mathrm{~kg} \mathrm{~m}^{-3}$ olmuștur.

Key words: Domates, sera, damla sulama, verim, kalite

\section{The Effect of Different Irrigation Levels on the Yield and Quality of Tomatoes in Greenhouse}

\begin{abstract}
This study was carried out in 2012-2013 season in the in the Mediterranean climate conditions to establish the optimum irrigation schedule for tomato (Lycopersicon esculentum Mill cv. Astona) in greenhouses. The experiment was conducted as a randomized block design with three replications as different irrigation levels. Different ratios of the amount of evaporation 160\%, 80\%, 100\%, and 120\%) from ClassA Pan was based on irrigation scheduling. The effects of different irrigation levels was significantly found on tomato yield and some quality criteria. The most appropriate irrigation program could be recommended that 100\% of open water surface evaporation should be applied as the amount of irrigation water. The requirement of irrigation water, marketable yield, irrigation water use efficiency for the recommended irrigation scheduling were $350 \mathrm{~mm}, 360,128.7 \mathrm{t} \mathrm{ha}^{-1}, 36.8 \mathrm{~kg} \mathrm{~m}^{-3}$, respectively.
\end{abstract}

Anahtar Kelimeler: Tomato, greenhouse, drip irrigation, yield, quality

\section{Gíriș}

Tarımsal üretimde, en önemli girdilerden birisi sulamadır. Su kaynaklarının kısıtı olmasınınyanında sanayi ve kentsel su gereksiniminin artması, sulamada kullanılan suyun azalmasına ya da kalitenin düșmesine neden olmaktadır (Özbahçe ve Tarı, 2009). Bu durum azalmakta olan sulama suyundan en yüksek yararın sağlanabilmesini yani birim alandan birim su ile daha fazla ürün elde edilmesini zorunlu kılmaktadır (Ertek vd., 2002).

Su kaynaklarının ve tarım arazilerinin azalmasının yanında nüfustaki artıș dikkate alındığında iklimsel kısıtların olumsuz etkilerini 
de azaltarak birim alandan daha yüksek verim alınması büyük önem arz etmektedir. Tarımda en fazla ürün artıșı, çevre koșullarına bağlı olmadan seralarda ya da örtü altı yetiștiricilikte sağlanabilir. Aynı zamanda pazara sürekli taze sebze ve meyve verebilmek tarımda mevsimlik ișgücü kullanımını tüm mevsim boyunca değerlendirmek ancak seracilıkla mümkündür (Yüksel, 1995). Buna ek olarak, sera teknolojisi çeșitli șekillerde su, çevre kirliliği ve ekolojik sistemin istikrarsızlığı gibi küresel sorunları çözmek için katkıda bulunabilir (Hashimoto, 2000).

Ülkemiz sebze tarımında domates, gerek seracilıkta gerekse tarlada önemli bir yere sahiptir. çünkü ülkemizde 1871637 dekar alanda yetiștiriciliği yapılmakta olup yılda alandan yaklașık 13 milyon ton üretim gerçekleștirilmektedir. Bu üretimin de \%27'si örtü altı yetiștiriciliğinden elde edilmektedir (TUIK, 2016).

Örtü altı yetiștiriciliği, diğer tarım kolları arasında yüksek tesis ve ișletme giderleri gerektiren, daha fazla teknik bilgi ve beceri ile sürekli ve daha çok uğrașı isteyen bir ișletme biçimi olmakla birlikte, birim alandan daha fazla ürün elde edilmesini sağlamakta ve açıkta üretilen ürünlerin pazara arzından önceki periyot içinde pazarda yer alması ile yüksek bir fiyat elde etmek suretiyle ișletme karını artırmakta ve tarımda gizli ișsizliğin azaltılmasına olanak sağlamaktadır (Pezikoğlu, 1999). Ülkemizde örtü altı yetiștiriciliği ekolojik koșullara bağı olarak geliștiğinden özellikle güney kıyılarımızda yoğunlașmıștır. Ülkemiz genelinde 663621 da alanda örtü altı yetiștiriciliği yapılırken bunun 162508 dekarı Mersin ilinde bulunmaktadır. Araștırmanın yürütüldüğü Silifke'de 5044 da alanda örtü altı yetiștiriciliği yapılmaktadır (TUiK, 2016).

Seracillk maksimum gelir elde edilmesi amacıyla uygun çevre koșullarının sağlanması için bașvurulan bir yetiștiricilik sistemidir (Von Zabeltitz, 1999). Bu koșullardan biri bitkinin gereksinimi olan suyun sağlanmasıdır. Çünkü sulama bitkisel üretimde verim artıșını en fazla etkileyen tarımsal faaliyettir. Bu nedenle Akdeniz Havzasında örtü altında yetiștirilen sebzeler için optimum sulama programının olușturulması amacıyla araștırmalar yürütülmektedir. Bu araștırmalarda genellikle açık su yüzeyi buharlașmasından yararlanılmaktadır (Abou-Hadid vd., 1994; Tüzel vd., 1994) Ülkemizin farklı bölgelerinde de örtü altında yetiștirilen bitkilerin optimum sulama programlarını elde etmeyi amaçlayan bazı araștırmalar yürütülmüștür (Derviș vd., 1992; Ekici, 2002; Kırda vd., 2004; Tüzel vd., 2005).

Serada domates yetiștiriciliğinde diğer tarımsal uygulamaların yanında, sulamadan en etkin bir biçimde yararlanmak, yüksek verim ve kaliteyi sağlamak için bitkilere verilecek sulama suyu miktarı ve zamanının bilinmesi gerekir. Bu çalıșma, cam sera koșullarında domates bitkisine uygulanan farklı miktarlardaki sulama suyunun domatesin verim ve kalitesine etkisini belirlemek amacıyla yürütülmüștür.

\section{MATERYAL ve METOT}

Araștırma, Mersin'in Silifke ilçesinde $36^{\circ} 22^{\prime}$ kuzey enlemi ve $33^{\circ} 5^{\prime}$ doğu boylamında yer alan Meslek Yüksek Okulu arazindeki cam serada yürütülmüștür. Söz konusu sera 21 metre uzunluğunda ve 6.5 metre genișliğinde olup kuzey-güney yönünde konușlu, $136.5 \mathrm{~m}^{2}$ büyüklüğündedir. Alüvyal topraklar grubunda yer alan deneme alanı topraklarının bazı özellikleri Çizelge 1'de verilmiștir.

Araștırmanın yürütüldüğü bölgede tipik Akdeniz iklimi görülür. Yazlar sıcak ve kurak, kıșlar ılık ve yağıșıdır. Uzun yıllık meteorolojik verilere göre, yörenin uzun yıllık yağıș ortalaması 572.2 mm'dir. Bölgede uzun yıllık sıcaklık ortalaması $17.8^{\circ} \mathrm{C}$, yıllık buharlașma ise 1608 mm'dir (DMi, 2015).

Araștırmanınyürütülmesinde gerekli olan sulama suyu, deneme alanında bulunan derin kuyudan temin edilmiș olup $T_{2} A_{1}$ sınıfına girmektedir.

Çizelge 1. Deneme yeri topraklarına ilișkin bazı fiziksel ve kimyasal özellikler

Table 1. Some physical and chemical properties of the soil experimental site

\begin{tabular}{|c|c|c|c|c|c|c|c|c|c|}
\hline \multirow{2}{*}{$\begin{array}{c}\text { Derinlik } \\
(\mathrm{cm})\end{array}$} & \multirow{2}{*}{$\mathrm{pH}$} & \multirow{2}{*}{$\begin{array}{c}E C \\
\left(\mathrm{dS} \mathrm{m}^{-1}\right)\end{array}$} & \multirow{2}{*}{$\begin{array}{c}\mathrm{CaCO} 3 \\
(\%)\end{array}$} & \multicolumn{3}{|c|}{ Bünye (\%) } & \multirow{2}{*}{$\begin{array}{c}\text { TK } \\
\left(\mathrm{g} \mathrm{g}^{-1}\right)\end{array}$} & \multirow{2}{*}{$\begin{array}{c}\text { SN } \\
\left(\mathrm{g} \mathrm{g}^{-1}\right)\end{array}$} & \multirow[t]{2}{*}{$\begin{array}{c}\mathrm{HA} \\
\left(\mathrm{g} \mathrm{cm}^{-3}\right)\end{array}$} \\
\hline & & & & Kum & Kil & Silt & & & \\
\hline $0-30$ & 7.9 & 0.74 & 23.2 & 18 & 57 & 25 & 28.71 & 19.54 & 1.39 \\
\hline $30-60$ & 7.9 & 0.68 & 26.1 & 16 & 61 & 23 & 27.12 & 19.41 & 1.61 \\
\hline $60-90$ & 8.0 & 0.62 & 31.2 & 12 & 65 & 23 & 28.71 & 21.34 & 1.61 \\
\hline
\end{tabular}


Denemenin kurulması amacıyla ağustos ayında bir önceki dönemden kalan bitkisel materyal sökülerek seranın içerisi temizlenmiștir. Daha sonra pullukla sürülen sera toprağı sulandıktan sonra 5 hafta süreyle solarizasyon uygulanmıștır. Solarizasyondan sonra tekrar sulanan deneme alanına tava geldikten sonra $5 \mathrm{~kg} \mathrm{da}^{-1} \mathrm{~N}$ ve 5 $\mathrm{kg} \mathrm{da}^{-1} \mathrm{P}_{2} \mathrm{O}_{5}$ olacak șekilde gübre uygulanarak rotovatörle sürülerek dikime hazır hale getirilmiștir. Deneme süresince $K_{100}$ konusuna fertigasyon yoluyla $100 \mathrm{mgl}^{-1}$ saf azot, $30 \mathrm{mg} \mathrm{l}^{-1}$ saf fosfor ve 150 $\mathrm{mg} \mathrm{l}^{-1}$ saf potasyum uygulanmıștır (Papadopoulos, 1987). Diğer konulara da $K_{100}$ konusuna verilen gübre miktarına denk gelecek șekilde, farklı gübre konsantrasyonları hazırlanarak uygulanmıștır.

6 Kasım 2012 tarihinde dikim ișlemi yapılmıștır. Dikim öncesinde 1.50 m genișliğinde ve $5.60 \mathrm{~m}$ uzunluğunda olacak șekilde deneme parselleri olușturulmuștur. Daha sonra her bir parsele, bölgede dikim mesafesi olarak tercih edilen, 0.75 m sıra aralığı ve 0.40 m sıra üzeri aralığı olacak șekilde iki sıra fide dikimi yapılmıș dolayısı ile her bir parselde 28 adet bitki yer almıștır. Denemede piyasadan temin edilen, sofralık Astona F1 (5825) sırık domates çeșidi kullanıımıștır.

Dikimden hemen sonra bitkilere can suyu verilmiștir. Ardından her bitki sırasına bir lateral gelecek șekilde damla sulama sistemi döșenmiștir. Bu sistem kullanılarak konulu uygulamalar öncesinde 2 kez yapılan fiks su uygulaması yapılmıștır. Dikimden 3 hafta sonra çapalama ve domates yetiștiriciliğinde bitkinin adventif kök olușturma özelliğine sahip olmasından dolayı önemli bir uygulama olan boğaz doldurma ișlemi yapılmıștır. Ayrıca gerektikçe çapalama ve ot temizliği yapıımıștır.

Denemede koltuk sürgünleri gözlemlenerek ortalama sürgün boyları 3 cm olduğunda kesilerek uzaklaștıııımıștır. Deneme süresince ișlevini yitirmiș, yașlı, zarar görmüș ve yere değen yaprakların alındığı alt yaprak budamaları yapıımıștır. Dikimden 30 gün sonra koltuk sürgünü budamasına bașlanmıștır. Bu ișlem Mayıs ayı sonunda kadar sürdürülmüș ve tüm vejetasyon dönemi boyunca 16 kez tekrarlanmıștır. Ürünlerin ekonomik önemini yitirmeye bașladığı sera domates üretim mevsiminin sonuna yaklașıldığı dönemde bitkinin daha fazla uzamasını engellemek ve üzerinde mevcut bulunan meyvelerin daha erken kızarmasını sağlamak amacıyla en üstteki çiçek salkımından sonra iki yaprak bırakılarak tepe budaması yapılmıștır. Bitkilerde domates meyveleri așağıdan yukarıya doğru hasat edildikçe ve alt yaprak budamalarından sonra yapraksız kalan gövde kısmı yaprakların bașladığı noktaya kadar paralel gelecek șekilde yatııımıștır. Böylece bitki boyunu bir miktar kısaltılarak bakım ișlemleri ve hasat kolaylaștırılımıștır. Araștırma, tesadüf blokları deneme deseninde 3 tekerrürlü olarak yürütülmüștür. Deneme konuları, açık su yüzeyi buharlașmasının farklı oranlarının $\left(k_{p}\right)$, sulama suyu olarak uygulanması esasına göre olușturulmuș olup, konular Çizelge 2'de gösterilmiștir.

Çizelge 2. Deneme konuları

Table 2. Experiment treatments

\begin{tabular}{cc}
\hline Konu adı & $k_{0}$ katsayıları \\
\hline$K_{60}$ & 0.60 \\
$K_{80}$ & 0.80 \\
$K_{100}$ & 1.00 \\
$K_{120}$ & 1.20 \\
\hline
\end{tabular}

Deneme alanının sulanmasında damla sulama sistemi kullanılmıștır. Sistem, güç ünitesi, elek filtre, gübre tankı vana, su saati, manometreler, bağlantı parçaları, manifolt boru hatları, her parsele ait kontrol vanaları, lateral hatları ve damlatııılarından olușmuștur. Manifold hatları 32 mm dıș çaplı PE borulardan lateral hatları ise 16 mm dıș çaplı içten geçik yuvarlak PE borulardan tesis edilmiștir. Damlatıcılar lateral boyunca ve konular arasında su dağılımının homojen olması için sabit debili özellikte seçilmiștir. Sistemin lateral aralığı $75 \mathrm{~cm}$, damlatıcı aralığı $30 \mathrm{~cm}$, damlatıcı debisi $2 \mathrm{~L} \mathrm{~h}^{-1}$ ve ișletme basıncı 1.0 atm'dir.

Sera içerisine yerleștirilen Class A Pan kabından meydana gelen yığıșımlı buharlașma miktarı 20 mm $\pm 3 \mathrm{~mm}$ ulaștığında sulamalar yapılmıștır. Ölçülen buharlașma değerleri kp katsayısı ve ıslatma yüzdesi ile çarpılarak uygulanacak sulama suyu miktarı belirlenmiștir. Sulama suyu miktarının hesaplanmasında Eșitlik 1'den yararlanılmıștır (Tarı, 2016).

$$
\mathrm{I}=\mathrm{A} \times \mathrm{Ep} \times \mathrm{kp} \times \mathrm{P}
$$

Eșitlikte; I: Parsele uygulanan sulama suyunu (litre), A: Parsel alanı $\left(\mathrm{m}^{2}\right), \mathrm{E}_{\mathrm{p}}$ : Açık su yüzeyinden meydana gelen birikimli buharlașma miktarını (mm), kp: Deneme konusuna ilișkin katsayıyı, P: Islatma oranını ifade etmektedir. Islatma oranı (P), serada yapılan test sonucunda 0.70 olarak belirlenmiștir. 
Bitki su tüketiminin hesaplamasında toprağın 0-90 cm derinliği esas alınmıș ve Eșitlik 2 kullanılarak belirlenmiștir (James, 1988).

$$
E T=1+P+K-D-R \pm \Delta S
$$

Eșitlikte; ET: Bitki su tüketimini (mm), I: sulama suyunu (mm), P: yağıșı (mm), K: kapilar yükseliș̦i $(\mathrm{mm})$, D: derine süzülme kayıplarını $(\mathrm{mm})$, R: yüzey akıșı $(\mathrm{mm})$ ve $\Delta \mathrm{S}$ : toprak profilindeki nem değișimini $(\mathrm{mm})$ göstermektedir. Hesaplamalarda P, K, R ve D değerleri sıfır alınmıștır. Toprak nem ölçümleri orta tekerrürdeki parsellerde gravimetrik metot ile $90 \mathrm{~cm}$ derinliğindeki her 30 cm'lik katmanda yapılmıștır.

Sulama programlarının değerlendirilmesinde ise sulama suyu kullanım etkinliği (INWUE) ve su kullanım etkinlik değerlerinden (WUE) yararlanılmıștır. Bu değerler, Howell vd., (1990) tarafından bildirilen eșitliklerden (Eșitlik 3. ve Eșitlik 4.) hesaplanmıștır.

$$
\begin{aligned}
& \text { WUE }=E y / E T \\
& \text { IWUE=Ey/IR }
\end{aligned}
$$

Eșitliklerde; Ey ekonomik verimi $\left(\mathrm{kg} \mathrm{ha}^{-1}\right)$, ET mevsimlik su tüketimini (mm), ve IR toplam sulama suyu miktarını (mm) ifade etmektedir.

Elde edilen sonuçların istatistikî değerlendirmelerinde, sulama düzeyi ile verim ve verim unsurları arasındaki ilișkilerin değerlendirilmesinde SPSS paket programından yararlanılmıștır. Sonuçların yorumlanması ise Yurtsever (1984)'e göre yapıImıștır.

\section{BULGULARVE TARTIȘMA}

\section{Sulama suyu miktarı ve su tüketimi}

Araștırmada, fide dikiminin hemen ardından deneme parsellerine $15 \mathrm{~mm}$ can suyu verilmiștir. Dikiminden sonraki süreçte konulu uygulamalara bașlanıncaya kadarki dönemde 18.11.2012 tarihinde $15 \mathrm{~mm}$ ve 29.112012 tarihlerinde 20

Çizelge 3. Araștırma konularına uygulanan sulama suyu miktarları ve su tüketimleri

Table 3. Amounts of water consumption and irrigation water applied according to the treatments

\begin{tabular}{ccc}
\hline KONULAR & Sulama suyu, mm & Su tüketimi, $\mathrm{mm}$ \\
\hline $\mathrm{K}_{60}$ & 242 & 276 \\
$\mathrm{~K}_{80}$ & 296 & 325 \\
$\mathrm{~K}_{100}$ & 350 & 361 \\
$\mathrm{~K}_{120}$ & 404 & 406 \\
\hline
\end{tabular}

mm olmak üzere iki kez daha tüm konulara aynı miktarda sulama suyu uygulanmıștır. Çizelge 3'de deneme konularına uygulanan sulama suyu miktarları ve konuların su tüketim miktarları verilmiștir. Șekil l'de ise yığıșımlı sulama suyu miktarları gösterilmiștir.

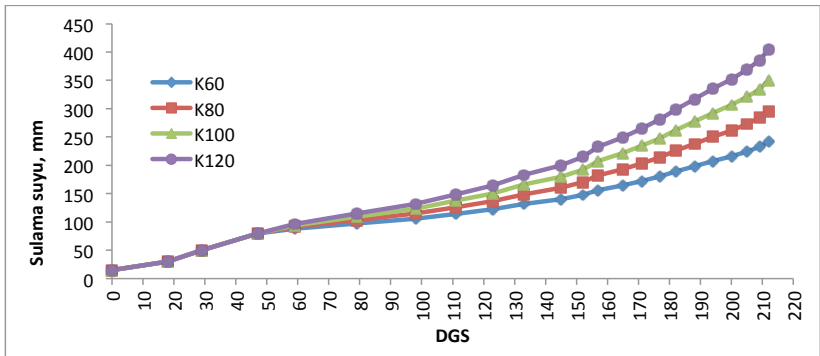

Șekil 1. Yığıșımlı sulama suyu miktarları

Figure 1. Cumulative amount of irrigation water

Araștırmada, konulu sulamalara 23 Aralık 2012 tarihinde tüm konular tarla kapasitesine getirilerek bașlanmıș ve 06.06.2013 tarihine kadar devam etmiștir. Yetișme dönemi süresince üçü can suyu ve adaptasyon sulaması olmak üzere toplamda 22 kez sulama yapılmıștır. Șekil 1'de görüldüğü gibi dikimden sonra geçen gün sayısı (DGS) 150 oluncaya kadar 10-12 gün aralıklarla devam eden sulamalar, günlerin uzaması, sıcaklıkların artması ve bitkilerin gelișmesine bağlı olarak nisan ayından itibaren 5-7 gün aralıklarla devam etmiștir. Mayıs ayının ortasından hasada kadar geçen dönemde ise sulama aralığı 3 güne kadar düșmüștür.

Deneme konularına verilen sulama suyu miktarları Pan katsayısına $\left(k_{p}\right)$ bağlı olarak değișiklik göstermiștir. Pan katsayısı 0.60 olan $\left(K_{60}\right)$ konuya toplam $242 \mathrm{~mm}$ sulama suyu uygulanırken, en fazla sulama suyu $\mathrm{K}_{120}$ konusuna verilmiștir. Bu konunun toplam sulama suyu miktarı 404 mm olmuștur (Çizelge 3). Deneme konularına uygulanan sulama suyu miktarları, tarla denemelerinde uygulanan sulama suyu miktarlarından daha az olmuștur (Çetin ve Uygan, 2008; Özbahçe ve Tarı, 2010). Sera koșullarında yapılan çalıșmalarda Topçu vd., (2007) 314 mm, Kırda vd., (2004) 345 mm, Derviș vd., (1 992) 403 mm sulama suyu önermișlerdir. Bu değerler bu araștırmada önerilen $K_{100}$ konusuna uygulanan sulama suyu miktarına benzerlik göstermektedir. Denemenin yürütüldüğü sera koșullarına, deneme yılına ilișkin iklim koșullarına ve yetiștirilen çeșidin özelliklerine bağlı olarak sulama suyu miktarlarında bir miktar farklılıklar ortaya çוkabilmektedir. Araștırma konularına verilen sulama suyu miktarları 
konulara ait su tüketimlerinin belirleyicisi olmuștur. Cok sulama suyu uygulanan konuların su tüketim değerleri yüksek olurken sulama suyundaki azalmaya bağlı olarak su tüketimleri de azalmıștır. En yüksek su tüketimi 406 mm ile $\mathrm{K}_{120}$ konusunda, en az su tüketimi ise 276 mm ile $K_{60}$ konusunda gerçekleșmiștir

\section{Verim ve kalite}

Bitkilerde ilk çiçekler Aralık ayı bașında görülmeye bașlamıș ve 27 Mart tarihinde ilk hasat yapılmıștır. Çizelge 4'de konulardan elde edilen toplam meyve verimleri ve bazı kalite değerleri verilmiștir.

Araștırmada, Mart ayı sonunda bașlanan hasat ișlemine 11 Haziran tarihine kadar devam edilmiș ve bu dönemde toplam 12 kez hasat yapılmıștır. Çizelge 4'de görüldüğü gibi uygulanan sulama suyu miktarına bağlı olarak deneme konularından $68.4 \mathrm{t} \mathrm{ha}^{-1}$ ile $128.7 \mathrm{t} \mathrm{ha}^{-1}$ arasında verim elde edilmiștir. Uygulanan sulama suyu miktarı bir düzeye kadar verim artıșına neden olurken, bu düzeyden daha fazla uygulanan sulama suyunun verim üzerinde olumsuz etkisi olmuștur. En yüksek verim pan katsayısı 1.00 olan $\mathrm{K}_{100}$ konusundan elde edilmiștir. Derviș vd., (1992) ise aynı bölgede yaptıkları araștırmada en yüksek verimi pan katsayısı 1.20 olan konudan elde etmișlerdir. Bu farkılığa, yetiștiricilikte yapılan uygulamalar ve sera koșulları neden olabilir.

Deneme konularından elde edilen domates verimleri istatistiki olarak değerlendirildiğinde, konular arasında \%1 önem seviyesinde farklılık görülmüștür. Buna bağlı olarak konulardan elde edilen verim sonuçları Duncan gruplandırması ile değerlendirilmiștir. Duncan testi sonucu deneme konularının verimleri 3 ayrı grupta yer almıș olup, $\mathrm{K}_{100}$ konusu tek bașına ilk grupta yer almıștır. Sulama suyunun verim ve kuru madde üzerine etkisi regresyon analizi ile değerlendirilmiș ve elde edilen ilișkileri gösteren grafikler Șekil Z'de verilmiștir.
Kuru madde oranı domateste önemli bir kalite kriteridir. Araștırmadan elde edilen bulgulara göre konulara uygulanan sulama suyu miktarı arttıkça meyvenin içerdiği kuru madde oranında azalma meydana gelmiștir. Artan sulama suyuna karșllık meyvede kuru madde oranının azalmasını, aynı konuda araștırmayapan diğer araștıııılar tarafından da tespit edilmiștir (Branthome vd., 1994; Elkner vd., 1993; Tan, 1995; Cevik vd., 1997; Kırnak ve Kaya, 2004; Kırda vd., 2004). En düșük kuru madde oranı \%4.53 ile $\mathrm{K}_{120}$ konusunda bulunurken en yüksek kuru madde oranı ise $\% 5.53$ ile $\mathrm{K}_{60}$ konusunda bulunmuștur. Bu oranlar arasındaki farklar istatistiki değerlendirme sonucunda \%1 önem seviyesinde önemli bulunmuștur. Yapılan Duncan testi sonucu konular 3 ayrı grupta yer almıș ve $\mathrm{K}_{60}$ konusu ilk grubu olușturmuștur.

Kuru madde oranının yanında kuru madde miktarı da domates bitkisinde dikkate alınan bir diğer önemli kalite göstergesidir. Kuru madde miktarını domates verimi ile kuru madde oranı etkilemektedir. Araștırmadan elde edilen kuru madde miktarları değerlendirildiğinde en fazla kuru madde verimin en fazla alındığı $K_{100}$ konusundan elde edilmiștir. Bu konuyu verimdeki azalmaya bağlı olarak diğer konular takip etmiștir. Sulama suyu miktarı ile kuru madde arasındaki ilișki önemli bulunmuștur (Șekil 2).

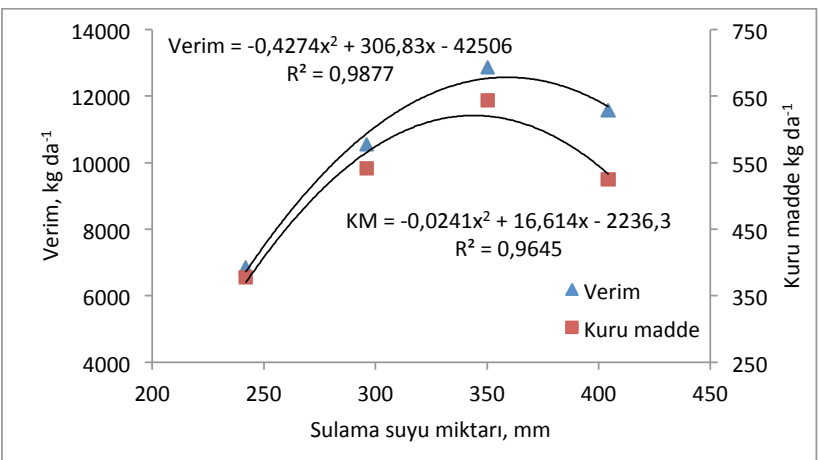

Șekil 2. Sulama suyu miktarı ile verim ve kuru madde ilișkisi Figure 2. The relationship between of irrigation water with yield and dry matter

Çizelge 4. Deneme konularına ilișkin domates verimi ve bazı kalite özellikleri

Table 4. Tomato yield and some quality properties of experiment treatments

\begin{tabular}{cccccccc}
\hline Konular & $\begin{array}{c}\text { Verim } \\
\mathrm{t} \mathrm{ha}^{-1}\end{array}$ & $\begin{array}{c}\text { Kuru madde } \\
\%\end{array}$ & $\begin{array}{c}\text { Kuru madde } \\
\mathrm{t} \mathrm{ha}^{-1}\end{array}$ & $\begin{array}{c}\text { Ort. meyve } \\
\text { ağıllığı } \mathrm{g}\end{array}$ & $\mathrm{pH}$ & $\begin{array}{c}\text { Meyve delinme } \\
\text { direnci, bar }\end{array}$ & $\begin{array}{c}\text { vitamini mg } \\
100 \mathrm{ml}^{-1}\end{array}$ \\
\hline $\mathrm{K}_{60}$ & $68.4 \mathrm{c}$ & $5.53 \mathrm{a}$ & $3.784 \mathrm{c}$ & $104 \mathrm{c}$ & $4.33 \mathrm{~b}$ & $1.21 \mathrm{c}$ & $9.26 \mathrm{a}$ \\
$\mathrm{K}_{80}$ & $105.5 \mathrm{~b}$ & $5.13 \mathrm{~b}$ & $5.418 \mathrm{~b}$ & $119 \mathrm{~b}$ & $4.40 \mathrm{~b}$ & $1.27 \mathrm{~b}$ & $8.52 \mathrm{~b}$ \\
$\mathrm{~K}_{100}$ & $128.7 \mathrm{a}$ & $5.00 \mathrm{~b}$ & $6.440 \mathrm{a}$ & $130 \mathrm{a}$ & $4.43 \mathrm{~b}$ & $1.37 \mathrm{a}$ & $7.69 \mathrm{c}$ \\
$\mathrm{K}_{120}$ & $115.8 \mathrm{ab}$ & $4.53 \mathrm{c}$ & $5.253 \mathrm{~b}$ & $124 \mathrm{ab}$ & $4.58 \mathrm{a}$ & $1.36 \mathrm{a}$ & $7.62 \mathrm{c}$ \\
\hline
\end{tabular}


Deneme süresince her hasatta meyve örneklemeleri yapılarak konuların ortalama meyve ağırlıkları belirlenmiștir. Belirlenen ortalama meyve ağırlıkları 104 gram ile 130 gram arasında değișmiștir (Çizelge 4). Uygulanan sulama suyu miktarına bağlı olarak meyve ağılı̆ı bir miktar artıș göstermiș sonra verimde de olduğu gibi düșüș göstermiștir. Daha önce serada çalıșan araștırıcılar da benzer sonuçlara ulașmıșlardır (Çevik ve vd., 1997; Kırda vd., 2004). En yüksek meyve ağırlığı $\mathrm{K}_{100}$ konusundan elde edilmiștir. En az sulama suyu uygulanan konunun meyve ağırlığı ise en düșük olmuștur. Konulara ait ortalama meyve ağırlıkları \% 1 önem seviyesinde farklı bulunmuștur.

$\mathrm{pH}$ domatesin kalite yönünden değerlendirilmesinde dikkate alınan bir diğer ölçüttür. Bu araștırmada alınan meyve örneklerinin meyve sularında yapılan ölçümlerde deneme konularında su kısıntısı arttıkça $\mathrm{pH}$ değerlerinde düșüș gözlenmiștir. En az suyun uygulandığı $\mathrm{K}_{60}$ konusunda 4.33 olan $\mathrm{pH}$, suyun en fazla uygulandığı $K_{120}$ konusunda 4.58 olarak ölçülmüștür. Konuların pH değerleri arasındaki farklılașma istatistiki olarak da önemli bulunmuștur. Topçu vd. (2007)'de su kısıntısının pH değerini düșürdüğünü ifade etmișlerdir. Ancak, Çukurova'da yapılan bașka bir sera çalıșmasında ise sulamadaki kısıntının domateste $\mathrm{pH}$ üzerine etkisi olmadığı ifade edilmiștir (Kırda vd., 2004).

Sofralık domateste meyvelerin delinme direnci ve C vitamini içerikleri, önemli kalite kriterleri olup yetiștiricilikte uygulanan tarımsal ișlemlerden önemli düzeyde etkilenmektedir. Yürütülen bu araștırmanın sonuçlarına göre uygulanan sulama suyu arttıkça domatesin meyve sertliği de artmıștır. Araștırmada, en çok kısıntının uygulandığı konunun meyve delinme dirençleri 1.21 bar iken optimum su uygulamasında bu değer 1.37 bar olmuștur. Ekici (2002)'de daha fazla sulama suyu uyguladığı konuların delinme dirençlerinin daha yüksek olduğunu ifade etmiștir. Bu araștırmada elde edilen bir bașka sonuca göre, su kısıntısı domatesin C vitamini içeriğini artırmaktadır. Açık su yüzeyi buharlașmasının 1.20 katının sulama suyu olarak uygulandığı $\mathrm{K}_{120}$ konusunun $\mathrm{C}$ vitamini içeriği $7.62 \mathrm{mg} 100 \mathrm{ml}^{-1}$ iken bu konunun yarısı kadar sulama suyu uygulanan konuda söz konusu

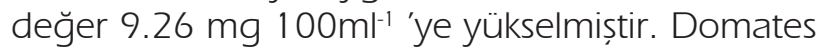
bitkisinde yürütülmüș olan bir araștırmada sulama düzeyi ile C vitamini miktarının değișmediğini ancak hasada doğru artıș gösterdiği bildirilmiștir (Ekici, 2002).

\section{Su kullanma randımanları}

Sulama suyu kullanım randımanı (IWUE) ve su kullanım randımanı (WUE) sulama uygulamalarının değerlendirilmesinde önemli göstergelerdir. Bu çalıșmada, sulama suyu miktarına bağlı olarak IWUE ve WUE değerleri de farklılık göstermiștir. Șekil 3'de deneme konularına ilișkin su kullanım randımanları grafiksel olarak gösterilmiștir.

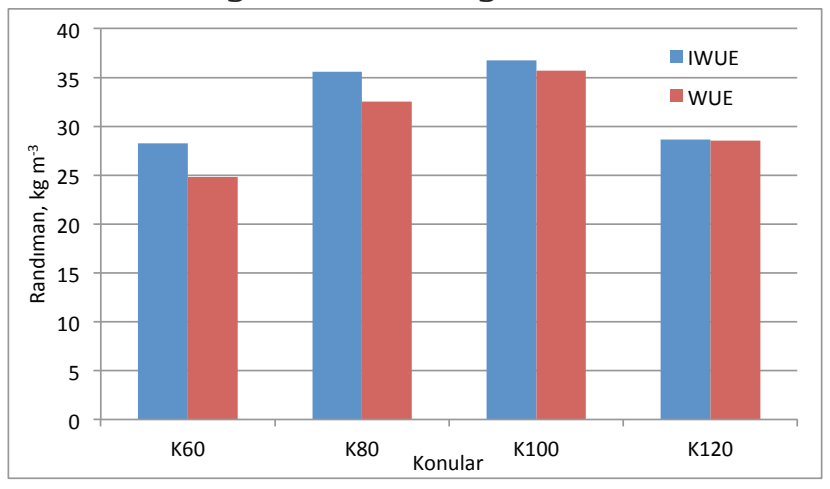

Șekil 2. Deneme konularına ilișkin su (WUE) ve sulama suyu (IWUE) kullanım randımanları

Figure 2. Irrigation water use efficiency (IWUE) and Water use efficiency (WUE) values for the experimental treatments

Șekil 3'de görüldüğü gibi, WUE değerleri $24.8 \mathrm{~kg} \mathrm{~m}^{-3}$ ile $35.7 \mathrm{~kg} \mathrm{~m}^{-3}$ arasında; IWUE değerleri ise $28.3 \mathrm{~kg} \mathrm{~m}^{-3}$ ile $36.8 \mathrm{~kg} \mathrm{~m}^{-3}$ arasında değișmiștir. Sulama düzeyi arttıkça randımanlar da artmıștır. Ancak bu artıș açık su yüzeyi buharlașmasının \%100 seviyesine kadar devam etmiș daha fazla sulama suyunun uygulanması ile düșüș göstermiștir. Daha önce yürütülen tarla denemelerinde Özbahçe ve Tarı, (2010) IWUE değerini $12.0 \mathrm{~kg} \mathrm{~m}^{-3}$ Çetin ve Uygan, (2008) $15.3 \mathrm{~kg} \mathrm{~m}^{-3}$ bulurken, sera denemesinde Kırda vd. (2004) $32.2 \mathrm{~kg} \mathrm{~m}^{-3}$ bulmușlardır. Bu sonuçlar örtü altı yetiștiriciliğinde su kullanım randımanının tarla yetiștiriciliğine göre çok yüksek olduğunu göstermektedir.

\section{SONUÇLAR}

Bu araștırmanın sonuçlarına göre, sera koșullarında damla sulama ile sulanan domates yetiștiriciliğinde, pan kabından olan buharlașma miktarının 1.0 katı kadar sulama suyunun (toplam $350.2 \mathrm{~mm}$ ) verilmesi uygun bulunmuștur. Önerilen uygulamaya göre yapılan sulamadan göre en yüksek verim (128.7 tha ${ }^{-1}$ ) ve en yüksek sulama suyu kullanım randımanı $\left(36.8 \mathrm{~kg} \mathrm{~m}^{-3}\right)$ elde edilmiștir. 
Buna göre nisan ayına kadar 10-12 gün aralıklarla sulamalar yapılmalı, nisan ayından itibaren iklim ve sera koșullarına bağlı olarak ilk altı hafta 5-7 gün aralıklarla, son dönem ise 3-5 gün aralıklarla sulamalara devam edilmelidir. Uygulanan sulama suyu miktarındaki artıș domateste ortalama meyve ağırlığını, meyve sertliğini ve toplam kuru madde miktarını artıırken, meyvede bulunan C vitamini miktarını ve kuru madde oranını düșürmüștür.

\section{KAYNAKLAR}

Abou-Hadid, AF, El-Shinawy MZ, El-Oksh I, Gomaa H, ElBeltagy AS (1994). Studies on waterconsumption of sweet pepper plant under plastic houses. Acta Hort. (ISHS) 366: 365-372.

Branthome X, Ple Y, Machado JR, Bieche BJ (1994). Influence of drip irrigation on the technological characteristics of processing tomatoes. Fifth International Symposium on the processing tomato, Sorrento, Italy, 23-27 November, 1993. Acta Horticulture, 376: 285-290.

Çetin Ö, Uygan D 2008. The effect of drip line spacing, irrigation regimes and planting geometries of tomato on yield, irrigation water use efficiency and net return . agri cultural water management 95: 949 - 958.

Çevik B, Abak K, Sarı N, Kırda C, Topaloğlu F (1997). Harran Ovası koșullarında damla sulama yöntemiyle sulanan bazı sebzelerde farkı su düzeylerinin verim ve kaliteye etkileri. 6. Kültürteknik Kongresi. Bildiriler: 316-323. 5-8 Haziran, Kirazlıyayla-Bursa.

Derviș Ö, Doğan M, Tok A, Ertekin Ü (1992). Antalya koșullarında cam serada tek ürün olarak yetiștirilen domatesin açık su yüzeyi buharlașmasında yaralanarak damla sulama sistemiyle sulanması. KHGM Tarsus Arșt. Enst. Yayınları 178/122, p. 73. kayıtları

DMi (2015). Devlet Meteoroloji İșleri Silifke Müdürlüğü

Ekici B (2002). Sera domates yetiștiriciliğinde kısmi kök kuruluğu (partial rootzone drying) sulama tekniğinin bitki büyümesi, verim ve meyve kalitesi üzerine etkileri. C..Ü. Fen Bilimleri Enst. Yüksek Lisans Tezi, p. 91, Adana.

Elkner K, Kaniszewski S, Gerasoponlos D, Olympios CH, Passam $\mathrm{H}$ (1993). Effect of drip irrigation and mulching on qualitiy of tomato fruits. International symposium on quality of fruit and vegatables: Influence of pre and post harvest factors and technology, 20-24 Sept. Chamia, Greece.

Ertek A, Șensoy S, Yıldız M, Kabay T (2002). Açık su yüzeyi buharlașmașından yararlanılarak sera koșullarında patlıcan bitkisi için en uygun sulama dozu ve aralığının belirlenmesi. K.S.Ü.Fen ve Mühendislik Dergisi, 5: 57-67.

Hashimoto Y (2000). Plant factory in the 21 st century. ICAME 2000 Proceedings of the Third International Conference on Agricultural Machinery Engineering, vol. I, Seoul, South Korea, pp. 1-13.

Howell TA, Cuenca RH, Solomon KH, (1990). Crop yield response. Manegement of farm irrigation systems, Edit. G.J. Hoffman., T.A. Howell., K.H. Solomon. Chap. 5. An ASAE Monograph, St. Joseph, Ml pp. 93-116.
James LG (1988). Prencipiles of farm irrigation system design. John Willey and sons inc., p. 453. New York

Kırda C, Çetin M, Dașgan Y, Topçu S, Kaman H, Ekici B, Derici MR, Özgüven Ai (2004). Yield response of greenhouse grown tomato to partial root drying and conventional deficit irrigation. Agricultural Water Management 69: 191-201.

Kırnak H, Kaya C (2004). Determination of irrigation scheduling of drip irrigated tomato using pan-evaporation in Harran Plain. GOÜ Ziraat Fakültesi dergisi 21 (1): 43-50.

Özbahçe A, Tarı AF (2009). Effects of different emitter spaces and irrigation levels on yield and yield components of processing tomato. Gaziosmanpașa Üniversitesi, Ziraat Fakültesi Dergisi, 26(2): 63-70.

Özbahce A, Tarı AF (2010). Effects of different emitter space and water stress on yield and quality of processing tomato under semi-arid climate conditions. Agricultural Water Management, Vol: 97(9): 1405-1410.

Papadopoulos I (1987). Nitrogen fertigation of Green House Grown Tomato. Communications in Soil Sci. And Plant Analysis, 18: 897-907.

Pezikoğlu F (1999). Örtü altı sebze yetiștiriciliği ve sorunları, Tarım Bakanlığı, Tarım ve Köy Dergisi, Sayı: 128, Ankara.

Tan CS (1995). Effect of drip and sprinkle irrigation on yield and quality of five tomato cultivars in southwestern Ontario. Canadian Journal of Plant Science, 75: 225-230.

Tarı AF (2016) The effects of lateral spacings and irrigation water levels on yield and sugar content of drip irrigated sugar beet in semi-arid region of Turkey. International Sugar Journal. 118(1407) 36-43.

Topcu S, Kirda C, DasganY, Kaman H, Çetin M, Yazici M, Bacon MA (2007). Yield response and $\mathrm{N}$-fertiliser recovery of tomato grown under deficit irrigation European of Journal Agronomy 26: 64-70.

TUIK 2016. https://biruni.tuik.gov.tr/bitkiselapp/bitkisel. zul (erișim tarihi 2/3/2016).

Tüzel Y, UI MA, Tüzel IH (1994). Effects of different irrigation intervals and rates on spring season glasshouse tomato production: II. Fruit quality. Acta Horticulturae, 366: 389-396.

Tüzel Y, Gül A, Dasgan HY, Özgür M, Özçelik N, Boyacı HF, Ersoy A (2005). Örtü altı yetiștiriciliğinde gelișmeler, Türkiye Ziraat Mühendisliği VI. Teknik Kongresi, 1.Cilt, 609627. 3-7 Ocak, 2005, Ankara

Von Zabeltitz C (1999). Greenhouse structures, ecosystems of the World's 20 greenhouses. Elsevier Publication, p 17-69. Amsterdam.

Yurtsever N (1984). Deneysel istatistik metotları. Toprak ve Gübre Araș. Enst. Genel Yayın No: 121, p. 623,Ankara.

Yüksel AN (1995). Sera yapım tekniği. Hasat Yayıncılık Ltd. Ști., II. Baskı, p. 335, İstanbul. 